\title{
PENGGUNAAN BAHAN PEREKAT EPOXY RESIN DAN CYANOACRYLATE PADA KONSERVASI KOLEKSI FOSIL DI MUSEUM MANUSIA PURBA SANGIRAN, JAWA TENGAH
}

\section{THE USE OF EPOXY RESIN AND CYANOACRYLATE ADHESIVES IN THE CONSERVATION OF FOSSIL COLLECTIONS AT THE SANGIRAN MUSEUM OF EARLY MAN, CENTRAL JAVA}

\author{
Pratamanita Widi Rahayu dan Andi Putranto \\ Departemen Arkeologi, Fakultas IImu Budaya, Universitas Gadjah Mada, Jalan Nusantara no. 1, Bulaksumur, Yogyakarta 55281, \\ Indonesia; posel: pratamanita.widi.r@mail.ugm.ac.id, andi.fib@ugm.ac.id
}

Diterima 12 Januari 2021

Direvisi 26 April 2021

Disetujui 20 Mei 2021

\begin{abstract}
Abstrak. Penelitian ini merupakan kajian museologi dengan pokok bahasan konservasi koleksi museum, terutama penggunaan bahan perekat terhadap koleksi museum. Permasalahan yang dibahas adalah dampak penggunaan bahan perekat terhadap koleksi fosil di Museum Manusia Purba Sangiran. Tujuan penelitian adalah untuk memahami metode konservasi fosil serta mengetahui jenis bahan perekat yang paling baik untuk digunakan dalam kegiatan konservasi fosil. Penelitian ini bersifat deskriptif-eksploratif dan menggunakan metode penalaran induktif. Pengumpulan data dilakukan dengan cara observasi, wawancara, dan studi pustaka. Analisis data dilakukan dengan mengamati sampel yang diperoleh dengan metode purposive sampling. Hasil penelitian menunjukkan bahwa fosil yang direkatkan dengan epoksi resin mengalami perubahan warna menjadi gelap kehitaman dan terdapat endapan residu resin pada permukaan fosil. Sementara itu, terdapat residu transparan mengilap di permukaan fosil yang direkatkan dengan lem cyanoacrylate.
\end{abstract}

Kata kunci: Museologi, Konservasi, Fosil, Bahan perekat, Sangiran

\begin{abstract}
This research is a study of museology with the subject of conservation of museum collections, especially the use of adhesive materials for museum collections. The problem discussed is the impact of the use of adhesive materials on the fossil collections at the Sangiran Museum of Early Man. The objective of this research is to comprehend the method of fossil conservation and to recognise the best type of adhesives to be used for fossil conservation. This research is descriptive-explorative and used the inductive reasoning method, and data were acquired by means of observation, interviews, and literature study. Data analysis was carried out by observing the samples obtained by the purposive sampling method. The results showed that the fossils glued with epoxy resin changed colour to dark black and there were resin residue deposits on the fossil surface. Meanwhile, there is a transparent residue showing a glossy appearance on the surface of the fossil which is glued together with cyanoacrylate adhesive.
\end{abstract}

Keywords: Museology, Conservation, Fossils, Adhesive, Sangiran

\section{PENDAHULUAN}

Dalam kaitannya dengan warisan budaya, museum adalah institusi yang merawat dan menjaga koleksi artefak dan benda-benda lain yang memiliki nilai penting ilmiah, seni, budaya, dan sejarah, serta mampu menyajikannya kepada publik melalui pameran (Lewis 1986). Berdasarkan Peraturan Pemerintah Republik Indonesia Nomor 19 Tahun 1995, museum merupakan lembaga tempat penyimpanan, perawatan, pengamanan, dan pemanfaatan benda-benda bukti materiil hasil budaya manusia serta alam dan lingkungannya guna menunjang upaya perlindungan dan pelestarian kekayaan budaya bangsa.

Koleksi museum pada umumnya adalah bahan ataupun objek penelitian ilmiah dalam bidang ilmu pengetahuan dan kebudayaan. Sembilan fungsi museum berdasarkan Direktorat Permuseuman Kementerian Pendidikan dan Kebudayaan adalah sebagai berikut,

- mengumpulkan dan mengamankan warisan alam dan budaya;

- dokumentasi dan penelitian ilmiah;

- konservasi dan preservasi;

- menyebarkan dan memeratakan ilmu untuk umum;

- mengenalkan dan menghayati kesenian; 
Penggunaan Bahan Perekat Epoxy Resin dan Cyanoacrylate Konservasi Koleksi Fosil di Museum Manusia Purba Sangiran, Jawa Tengah - Pratamanita Rahayu dan Andi Putranto (43-58)

Doi: $10.24832 / n w . v 15 i 1.454$

- mengenalkan kebudayaan antardaerah dan antarbangsa;

- visualisasi warisan alam dan budaya;

- cermin pertumbuhan peradaban umat manusia;

- membangkitkan rasa takwa dan bersyukur kepada Tuhan (Iswidarti 2015).

Berdasarkan fungsi museum yang telah dikemukakan tersebut, sudah seharusnya museum melakukan konservasi dan preservasi terhadap koleksinya. Konservasi dalam lingkup museum dan arkeologi adalah tindakan untuk memahami dan mengendalikan penyebab deteriorisasi serta tindakan yang diambil untuk memperbaiki kondisi koleksi tersebut (Agrawal 1997 dalam Sadirin 2014). Terdapat dua faktor penting dalam kegiatan konservasi, yaitu (1) tindakan pada saat ekskavasi atau pascaekskavasi untuk mengatasi deteriorasi yang mungkin terjadi; dan (2) pemeriksaan secara teliti, baik sebelum kegiatan konservasi maupun setelah kegiatan konservasi dilakukan untuk menentukan fungsi dari objek serta melihat pengaruh dari kondisi, baik pada saat objek masih terkubur maupun pada saat pelaksanaan kegiatan ekskavasi.

Oleh karena Sangiran merupakan salah satu situs penting berskala Warisan Budaya Dunia UNESCO yang berada di Indonesia, konservasi koleksi fosil merupakan hal yang harus diperhatikan. Fosil-fosil yang diperoleh sudah sewajarnya dirawat dan dipelihara untuk kepentingan generasi yang mendatang. Sebelum membahas konservasi dan tindakan yang dilakukan dalam konservasi koleksi fosil, ada baiknya situs Sangiran sebagai fokus penelitian ini dibahas terlebih dahulu.

Sangiran dikenal sebagai situs yang penting bagi ilmu pengetahuan, terutama di bidang evolusi manusia. Sejak Eugene Dubois melakukan penelitian di situs Sangiran pada tahun 1891 hingga 1893, ia telah menemukan satu gigi primata purba, atap tengkorak, serta femur bagian kiri (Widianto dan Simanjuntak 2009). Louis Jean-Chretien van Es kemudian memetakan situs Sangiran serta menerbitkan disertasinya yang berjudul "The Age of Pithecanthropus" pada tahun 1931. Dengan berbekal disertasi van Es, pada tahun 1934 G.H.R. von Koenigswald mulai melakukan penelitian di Sangiran dan menemukan alat-alat serpih batu di Bukit Ngebung. Penemuan fosil manusia purba pertama kalinya di Sangiran ialah pada tahun 1936 berupa fragmen fosil rahang bawah oleh Koenigswald. Sejak itu, Koenigswald dalam penelitiannya di situs Sangiran pada tahun 1937 hingga 1939 telah memperoleh fosil tengkorak wanita dan fosil rahang bawah (Widianto dan Simanjuntak 2009).

Situs Sangiran ditetapkan sebagai Kawasan Situs Cagar Budaya Nasional oleh pemerintah Indonesia sejak tahun 1977. Selain itu pula, situs Sangiran telah ditetapkan sebagai Warisan Budaya Dunia UNESCO pada tahun 1996. Hal tersebut menunjukkan betapa pentingnya keberadaan situs Sangiran. Oleh karena itu, Museum Manusia Purba Sangiran tidak hanya berfungsi untuk memamerkan temuan fosil mereka, tetapi juga sebagai tempat konservasi fosil yang diperoleh dari kawasan situs Sangiran.

Fosil yang ditemukan biasanya tidak dalam keadaan utuh. Kalaupun ditemukan utuh, fosil tersebut masih rentan pecah. Oleh karenanya, salah satu material bahan konservan yang penting dalam melakukan konservasi koleksi fosil adalah bahan perekat yang digunakan, terutama untuk menyambungkan potongan-potongan fosil (Howie 1984). Terdapat berbagai macam bahan dan jenis perekat yang digunakan dalam konservasi koleksi fosil, baik perekat alami maupun perekat sintetis . Bahan perekat alami, antara lain shellac, gum acacia atau gum arabic, dan lem protein hewani (Thornton 2005), sedangkan bahan perekat sintetis termasuk di antaranya polimer akrilik, epoksi, poliuretan, cyanoacrylate, dan butvar (Thornton 2005). Setiap bahan perekat yang biasa digunakan dalam konservasi fosil tersebut memiliki kelebihan serta kelemahan dalam penggunaannya. Dampak yang terjadi dari penggunaan bahan perekat tertentu terhadap koleksi fosil juga tidak selalu sama.

Permasalahan yang diajukan dalam penelitian ini adalah,

1. Bagaimana metode pemakaian bahan perekat dalam kegiatan konservasi kuratif terhadap koleksi fosil di Museum Manusia Purba Sangiran?

2. Bagaimana hasil serta dampak dari penggunaan bahan perekat tersebut terhadap koleksi fosil?

Tujuan penelitian ini adalah untuk menjelaskan penggunaan bahan perekat dalam konservasi yang dilakukan di Museum Manusia Purba Sangiran, sejak awal didirikannya pada tahun 1989 hingga tahun 2015. Selain itu, penelitian ini diharapkan dapat mengetahui sifat buruk bahan perekat sekaligus mengetahui bahan perekat yang paling baik untuk digunakan dalam kegiatan konservasi fosil di daerah dengan iklim tropis yang 
sesuai dengan standar penggunaan bahan konservan, terutama dalam konservasi kuratif fosil di Museum Manusia Purba Sangiran.

\section{METODE}

Penelitian ini bersifat deskriptif-eksploratif dan menggunakan metode penalaran induktif. Pengumpulan data dilakukan dengan cara observasi, wawancara, dan studi pustaka. Data primer yang dikumpulkan merupakan hasil observasi langsung koleksi fosil Museum Manusia Purba Sangiran beserta catatan-catatan sejarah konservasinya. Pengambilan sampel koleksi fosil untuk penelitian ini menggunakan purposive sampling yang merupakan salah satu teknik pengambilan sampel nonprobabilitas. Pada penelitian ini, sampel tersebut adalah koleksi fosil Museum Manusia Purba Sangiran yang telah diberi penanganan konservasi dengan menggunakan bahan perekat. Sementara itu, data sekunder dalam penelitian ini adalah data yang diperoleh melalui pengumpulan artikel-artikel dan laporan penelitian konservasi fosil yang telah dilakukan di luar negeri oleh peneliti dari Inggris dan Amerika Serikat, serta daftar bahan perekat yang digunakan beserta dampak negatif, kelemahan dan kelebihannya. Data hasil penelitian terdahulu mengenai sistem rekonstruksi fosil dan teknik konservasi dikumpulkan juga, baik hasil penelitian dari Museum Manusia Purba Sangiran itu sendiri maupun sumber lain. Dari data pustaka yang telah dikumpulkan kemudian dirumuskan metode konservasi fosil dan bahan perekat yang digunakan sebagai acuan penelitian.

Dalam analisis data akan diuraikan sistem rekonstruksi fosil yang dilakukan di Museum Manusia Purba Sangiran, kegiatan konservasi pada koleksi fosil, serta penggunaan bahan perekat dalam prosesnya. Hal yang diperhatikan antara lain adalah tampak permukaan fosil yang diberi bahan perekat, sambungan pada potongan serta fragmen fosil, serta penampakan fosil secara keseluruhan setelah proses konservasi. Penggunaan bahan perekat di Museum Manusia Purba Sangiran kemudian dibandingkan dengan penggunaan bahan perekat yang telah dilakukan oleh peneliti dari Inggris dan Amerika Serikat untuk melihat efektivitas dan dampak penggunaan bahan perekat tersebut pada sampel koleksi secara langsung. Selain itu, pada tahap analisis ini pula dilakukan pengamatan terhadap spesimen koleksi fosil yang telah dikonservasi dengan menggunakan bahan perekat. Analisis tersebut berdasarkan pada bahan perekat yang digunakan, tahun dilakukannya konservasi tersebut, serta dampak yang muncul atas penggunaan bahan perekat pada koleksi fosil.

Data dari Balai Penelitian Situs Manusia Purba Sangiran menyebutkan bahwa koleksi yang disimpan di ruang penyimpanan Museum Manusia Purba Sangiran sampai dengan bulan Agustus 2013 berjumlah 33.891 artefak. Akan tetapi, koleksi fosil yang telah didata ulang ke dalam database museum terbaru hingga bulan September 2015 berjumlah 8.787 fosil, yang meliputi fosil manusia, hewan, dan tumbuhan. Database terbaru museum dibagi menjadi dua bagian, yaitu, (i) database lama mencatat temuan yang didapatkan antara tahun 2009 hingga 2010 dengan beberapa temuan dari tahun sebelumnya; dan (ii) database baru mencatat koleksi yang diperoleh sejak tahun 2010 hingga September 2015. Selain database terbaru tersebut, terdapat database lama yang merekam koleksi temuan Museum Manusia Purba Sangiran sebelum tahun 2009. Perbedaan antara database lama sebelum tahun 2009 dan database terbaru antara 2010 — 2015, yaitu pada database terbaru disertakan lokasi koleksi museum di ruang penyimpanan sehingga keberadaan koleksi dapat dipantau.

Spesimen koleksi fosil yang diambil sebagai sampel penelitian ini terbatas pada fosil binatang dan alat tulang yang termasuk ke dalam kelompok fosil dan subfosil yang telah diberi penanganan konservasi dengan menggunakan bahan perekat. Dari total 8.787 fosil yang dicatat dalam database terbaru, koleksi yang diberi penanganan konservasi dengan menggunakan bahan perekat berjumlah 213 fosil. Angka tersebut diperoleh setelah dilakukan pengecekan database secara manual disebabkan tidak adanya keterangan penanganan konservasi pada koleksi fosil dalam database. Koleksi di Museum Manusia Purba Sangiran secara umum diklasifikasikan berdasarkan familinya. Terdapat pula koleksi yang dimasukkan ke dalam klasifikasi berdasarkan taksonomi kelas dan ordo. Dengan menyortir koleksi, baik berdasarkan famili, kelas, maupun ordo, serta kemudian memilih koleksi dengan keterangan "saat ditemukan patah beberapa bagian" atau "saat ditemukan kondisi pecah", koleksi dapat dikelompokkan ke dalam daftar koleksi yang diberi penanganan konservasi dengan menggunakan bahan perekat. 
Koleksi yang dijadikan sampel penelitian harus merupakan koleksi yang terdapat di ruang penyimpanan Museum Manusia Purba Sangiran dan keberadaaannya dapat dilacak. Oleh karena itu, sampel penelitian diambil dari koleksi fosil yang dicatat di dalam database terbaru. Koleksi fosil tersebut kemudian dikelompokkan berdasarkan klasifikasinya. Sebagai contoh, koleksi fosil yang telah diberi penanganan konservasi dengan bahan perekat, antara lain kelompok Elephantidae berjumlah 90 fosil, kelompok Bovidae berjumlah 50 fosil, dan kelompok Cervidae berjumlah 30 fosil. Penulis mengambil 10\% dari jumlah tersebut untuk dijadikan sampel penelitian sehingga didapatkan sampel koleksi sebanyak sembilan fosil dari kelompok Elephantidae, lima fosil dari kelompok Bovidae, serta tiga fosil dari kelompok Cervidae. Untuk kelompok klasifikasi lainnya, sampel diambil secara acak dengan kisaran kasar antara satu hingga tiga fosil dari setiap kelompok dan didapatkan 32 fosil sampel koleksi.

Setelah itu, sampel koleksi yang berjumlah 32 fosil tersebut dikelompokkan berdasarkan angka tahun yang tertera di nomor inventaris sehingga didapatkan sampel koleksi dari tahun 2009 hingga tahun 2015. Sembilan fosil koleksi yang dinilai dapat mewakilkan tiap kelompok tahun serta spesimennya diambil sebagai sampel penelitian. Sampel dari famili Elephantidae diambil sebanyak tiga fosil, karena jumlah koleksi dari kelompok klasifikasi tersebut merupakan koleksi yang telah diberi penanganan konservasi dengan bahan perekat paling banyak. Berikut daftar koleksi Museum Manusia Purba Sangiran yang diambil sebagai sampel penelitian (Tabel 1).

Tabel 1 Sampel Fosil yang Digunakan dalam Penelitian

\begin{tabular}{cclll} 
No & Tahun & \multicolumn{1}{c}{ Kelas/Famili/Species } & \multicolumn{1}{c}{ Bagian Fosil } & \multicolumn{1}{c}{ Nomor Inventaris (NIV) } \\
\hline 1. & 2009 & Famili Trionychidae & Plastron & Tri/0166/BPSMPS/09 \\
2. & 2010 & Stegodon sp. & Tulang atlas & Elp/1228/BPSMPS/10 \\
3. & 2010 & Stegodon sp. & Costae sinistra & Elp/0965/BPSMPS/10 \\
4. & 2010 & Bubalus palaeokarabau & Fr. cornu sinistra & Bov/0500/BPSMPS/2010 \\
5. & 2011 & Bos sp. & Mandibula dextra & Bov/1222/BPSMPS/2011 \\
6. & 2012 & Rhinoceros sp. & Fr. humerus dextra & $0086 /$ Rhi/BPSMPS/12 \\
7. & 2013 & Famili Elephantidae & Fr. pelvis & $1627 /$ Elp/BPSMPS/2013 \\
8. & 2014 & Kelas Mamalia & Fr. tulang kaki & $0022 /$ Mam/BPSMPS/2014 \\
9. & 2015 & Felis sp. & Ulna sinistra & $006 /$ Fel/BPSMPS/15 \\
\hline
\end{tabular}

Keterangan: Fr. = fragmen

Sumber: database Museum Manusia Purba Sangiran

\section{HASIL DAN PEMBAHASAN}

\section{Konservasi di Museum Manusia Purba Sangiran}

Langkah awal para teknisi konservasi dan konservator sebelum melakukan kegiatan konservasi pada koleksi fosil adalah mengamati fosil yang akan diberi penanganan konservasi dengan tujuan untuk mengenali bentuk asli dari fosil tersebut, mengamati apabila ada kerusakan pada fosil dan penyebab kerusakannya, serta tindakan konservasi yang akan dilakukan pada koleksi fosil tersebut. Hal ini dilakukan karena pada saat diperoleh biasanya fosil dalam keadaan tertutup endapan tanah ataupun kerak-kerak (manganese encrustation) dan rentan akan pelapukan fisik, kimiawi, dan biologis.

Konservasi kuratif di Museum Manusia Purba Sangiran terdiri atas dua bagian, yaitu pembersihan fosil dan perbaikan fosil. Koleksi fosil yang tidak memerlukan perbaikan rata-rata hanya dibersihkan, kemudian diberi lapisan pelindung agar koleksi fosil terhindar dari faktor-faktor yang dapat merusak kondisi material fosil. Perbedaan penanganan pada setiap spesimen koleksi fosil juga didasarkan pada kondisi fosil tersebut saat ditemukan. Apabila fosil dalam kondisi pecah atau terpotong-potong, fosil akan diberi penanganan konservasi berupa penyambungan untuk merekonstruksi bentuk dari fosil tersebut. Akan tetapi, apabila fosil diperoleh dalam keadaan utuh tetapi memiliki tingkat kekerasan yang rendah, fosil kemudian dikonsolidasi dengan menggunakan bahan konservan. Berikut uraian mengenai penanganan konservasi kuratif yang dilakukan di Museum Manusia Purba Sangiran (Sukronedi 2012). 


\section{Pembersihan Koleksi Fosil}

Tindakan pembersihan koleksi fosil dilakukan untuk menghilangkan debu, tanah, lempung, pasir, endapan kapur, serta kotoran-kotoran lain yang menempel di permukaan fosil. Berdasarkan metodenya, pembersihan koleksi fosil di Museum Manusia Purba Sangiran dibedakan menjadi dua, yaitu pembersihan secara mekanis dan pembersihan secara kimiawi.

Pembersihan secara mekanis (mechanical cleaning) adalah proses membersihkan permukaan fosil dengan menggunakan alat-alat seperti kuas, sikat ijuk, kain, sikat gigi, jarum panjang, ataupun scalpel scapula. Fosil yang permukaannya berpasir atau berdebu dapat dengan mudah dibersihkan dengan menggunakan kuas, sikat ijuk, atau sikat gigi. Akan tetapi, diperlukan scalpel scapula untuk membersihkan kotoran yang berupa endapan kapur, lempung, dan tanah. Konservator perlu berhati-hati saat menggunakan scalpel scapula dan jarum panjang sewaktu membersihkan fosil agar tidak menggores permukaan fosil.

Pembersihan kimiawi (chemical cleaning) dilakukan untuk membersihkan permukaan fosil dari kotoran-kotoran dan endapan yang tidak bisa dibersihkan dengan metode pembersihan mekanis. Metode pembersihan ini dinilai lebih aman karena tidak melibatkan gesekan langsung antara alat dan spesimen yang dibersihkan, serta tidak mengakibatkan, baik goncangan maupun getaran yang dapat merusak matriks fosil. Selain itu, pembersihan dengan menggunakan bahan kimia memungkinkan untuk membersihkan celah-celah sempit pada fosil yang tidak dapat dibersihkan secara mekanis. Bahan-bahan konservan yang digunakan untuk membersihkan permukaan fosil, antara lain Adexin ${ }^{\mathrm{TM}}$, etanol, alkohol, dan benzol. Cara mengaplikasikan bahan konservan pada fosil adalah dengan mengoleskan kuas yang telah dicelupkan dalam bahan konservan. Setelah menunggu beberapa saat, permukaan fosil tersebut disikat perlahan-lahan dengan menggunakan sikat gigi ataupun sikat ijuk. Proses tersebut dapat diulangi beberapa kali hingga permukaan fosil dinilai telah bersih. Setelah itu, fosil tersebut harus segera dibilas secara menyeluruh agar tidak ada sisa-sisa bahan kimia yang tertinggal pada fosil. Spesimen fosil yang telah dibilas harus dikeringkan sebelum diberi penanganan lebih lanjut.

\section{Perbaikan Koleksi Fosil}

Fosil yang diperoleh Museum Manusia Purba Sangiran tidak selalu dalam kondisi utuh. Tidak jarang pula fosil tersebut diperoleh dalam keadaan rapuh dan retak. Perbaikan koleksi fosil dilakukan setelah fosil tersebut dibersihkan. Tindakan perbaikan fosil, antara lain sebagai berikut,

\section{Penyambungan}

Rekonstruksi fosil merupakan kegiatan menyusun kembali potongan-potongan atau fragmen fosil agar menjadi satu. Terdapat dua metode untuk menyambungkan potongan atau pecahan fosil, yaitu penyambungan tanpa angkur dan penyambungan dengan angkur. Kedua metode ini sama-sama membutuhkan bahan konservan untuk merekatkan bagian-bagian fosil yang terpisah, tetapi angkur digunakan sebagai penyokong untuk fosil berukuran besar. Bahan konservan yang digunakan dalam penyambungan fosil berukuran kecil adalah lem super $\mathrm{G}$ Tong Shen yang termasuk bahan perekat cyanoacrylate, sedangkan bahan perekat yang digunakan untuk menyambungkan bagian-bagian potongan fosil yang berukuran besar adalah epoxy resin.

\section{Penginjeksian}

Tindakan lainnya dalam perbaikan fosil adalah penginjeksian. Fosil-fosil koleksi Museum Manusia Purba Sangiran seringkali ditemukan memiliki retak-retak yang terlihat jelas pada permukaannya meski fosil tersebut diperoleh dalam keadaan utuh dan tidak memerlukan tindakan penyambungan. Keretakan tersebut seringkali disebabkan oleh fluktuasi kelembapan relatif ( $\mathrm{RH}$; relative humidity), suhu, dan pengeringan yang tidak terpantau. Oleh karena itu, penginjeksian dilakukan untuk mengisi retak-retak pada permukaan fosil tersebut agar koleksi fosil tidak terdeteriorasi.

Penginjeksian dalam konservasi di Museum Manusia Purba Sangiran merupakan tindakan menyuntikan bahan perekat ke dalam retakan yang terdapat di permukaan fosil. Bahan perekat dengan viskositas rendah 
Penggunaan Bahan Perekat Epoxy Resin dan Cyanoacrylate Konservasi Koleksi Fosil di Museum Manusia Purba Sangiran, Jawa Tengah - Pratamanita Rahayu dan Andi Putranto (43-58)

Doi: $10.24832 / n w . v 15 i 1.454$

dipilih dengan tujuan agar bahan perekat tersebut dapat terpenetrasi ke dalam celah-celah retakan fosil dengan baik. Jumlah bahan perekat yang perlu disiapkan tergantung dari volume serta ukuran keretakan pada fosil tersebut. Penginjeksian bahan perekat pada retakan fosil dilakukan dengan menggunakan alat khusus semacam alat suntik (spuit atau spet). Bahan perekat diinjeksikan sedikit demi sedikit ke dalam celah retakan fosil dan kemudian didiamkan selama 24 jam hingga mengering.

\section{Penyelarasan Warna}

Tindakan berikutnya pada kegiatan konservasi kuratif fosil adalah kamuflase atau penyelarasan warna. Tindakan ini bertujuan untuk menyelaraskan warna antara bagian yang diberi penanganan konservasi dan warna asli fosil. Selain itu, penyelarasan warna dilakukan untuk menyamarkan sambungan yang terdapat pada fosil yang direkonstruksi. Bahan yang diperlukan, antara lain campuran pasir dan bubuk fosil, serta bahan perekat epoxy resin atau lem cyanoacrylate. Pemilihan bahan perekat yang akan digunakan tersebut bergantung pada penggunaan bahan perekat dalam tindakan penyambungan potongan fosil.

Campuran pasir dan bubuk fosil yang akan digunakan untuk menyelaraskan warna fosil didapatkan dari koleksi fosil itu sendiri. Pasir yang menempel pada temuan fosil dibersihkan dan kemudian dikumpulkan. Sementara itu, bubuk fosil diperoleh dari potongan serta pecahan fosil yang terlalu kecil dan tidak pas bila disambungkan dengan potongan fosil lainnya yang ada. Pecahan-pecahan tersebut ditumbuk sampai halus menjadi bubuk, kemudian dicampurkan dengan pasir dari temuan fosil sebelumnya.

Sebelum diaplikasikan pada koleksi fosil, campuran pasir dan bubuk fosil terlebih dahulu dicampurkan dengan bahan perekat. Tidak terdapat takaran baku dalam jumlah campuran pasir dan bubuk fosil dengan bahan perekat. Takaran perbandingan antara campuran bubuk fosil dan bahan perekat disesuaikan dengan kebutuhan dan warna asli fosil. Hal itu bergantung pada tiap-tiap konservator yang sedang dalam tugas menangani konservasi fosil tersebut.

Bahan kamuflase diaplikasikan pada bagian fosil yang ingin diselaraskan warnanya. Apabila bahan kamuflase tersebut tidak dapat merekat pada permukaan fosil, bahan perekat ditambahkan pada koleksi fosil sebelum mengaplikasikan bahan kamuflase. Bahan perekat dioleskan tipis-tipis secara merata dengan menggunakan kuas pada bagian yang akan diselaraskan warnanya dengan warna asli fosil dan kemudian bahan kamuflase dapat dioleskan setelahnya.

\section{Pelapisan}

Tindakan paling akhir dalam perbaikan fosil adalah coating dengan lapisan pelindung pada fosil yang telah dibersihkan dan diberi penanganan konservasi kuratif. Hal ini dilakukan dengan tujuan agar fosil yang telah dikonservasi terlindung dari faktor-faktor yang dapat menyebabkan pelapukan fisik, kimiawi, dan biologis pada koleksi tersebut. Selain itu, pelapisan dengan lapisan pelindung menjaga agar fosil tidak lembap dan berdebu.

Lapisan pelindung yang digunakan di Museum Manusia Purba Sangiran merupakan salah satu bahan konservan yang tersedia dan digunakan secara umum, yaitu Paraloid B-72 yang dilarutkan dengan etil asetat (ethyl acetate) dengan kadar larutan 1-3\%. Selain Paraloid B-72, polyvinyl acetate yang dilarutkan dengan etil asetat yang memiliki kadar larutan 1-3\%, juga digunakan sebagai lapisan pelindung koleksi fosil di Museum Manusia Purba Sangiran. Bahan-bahan konservan yang digunakan sebagai lapisan pelindung memiliki kelebihan, antara lain tahan akan kelembapan suhu ruang, transparan, dan tidak mengilap.

\section{Bahan Perekat dalam Konservasi di Museum Sangiran}

Bahan perekat yang dibahas tidak terbatas hanya pada bahan perekat yang digunakan pada tahun 2015, tetapi juga bahan perekat yang digunakan sejak Museum Manusia Purba Sangiran mulai melakukan kegiatan konservasi koleksi fosil pada tahun 1989. Keterangan mengenai penggunaan bahan perekat ini didapatkan melalui wawancara dengan narasumber serta pengamatan di laboratorium. Narasumber yang diwawancarai adalah Widiyono dan Utomo S. Y., keduanya adalah teknisi konservasi; Yudha H. I., salah satu konservator; Paiman, Seksi Logistik yang merupakan mantan konservator; serta Gunawan, pensiunan yang juga merupakan mantan konservator. 
Berdasarkan wawancara dengan Gunawan, salah satu konservator pertama di Museum Manusia Purba Sangiran, dapat diketahui sejarah penggunaan bahan perekat. Sebelum didirikannya Museum Manusia Purba Sangiran, pelaksanaan konservasi fosil berada di bawah Balai Pelestarian Peninggalan Purbakala Jawa Tengah. Pada saat itu konservasi terhadap tinggalan fosil, baik yang pecah maupun terpotong-potong dilakukan secara sederhana dengan menggunakan sambungan mekanik berupa angkur dan belum menggunakan bahan kimiawi sebagai konservan.

Koleksi fosil Museum Manusia Purba Sangiran diperoleh dari kegiatan ekskavasi dan serah simpan dari warga sekitar museum. Temuan fosil yang pecah dan terpotong-potong biasanya disambung dengan menggunakan semen oleh warga yang menemukannya, sebelum diserahkan ke museum. Selain menggunakan semen, potongan fosil juga sering kali disambung, baik dengan menggunakan lem racol (lem kayu) maupun lem plastic steel kemasan hitam dan putih. Keemahan lem racol adalah mudah luntur apabila dipanaskan meski berfungsi pula sebagai bahan pengawet, sedangkan lem plastic steel memiliki kekurangan mudah patah saat sambungannya mengering (wawancara dengan Gunawan).

Pada masa konservasi awal yang dilakukan Museum Manusia Purba Sangiran, lem UHU ${ }^{\text {TM }}$ digunakan sebagai bahan perekat sementara untuk menyambungkan potongan-potongan temuan fosil. Lem UHU ${ }^{\mathrm{TM}}$ tersebut dilarutkan dengan ethanol absolute atau alkohol sebelum diaplikasikan sebagai perekat pada potongan fosil. Pada tahun 1990 penggunaan lem UHU ${ }^{\mathrm{TM}}$ dihilangkan dan araldite mulai digunakan sebagai bahan perekat fosil.

Araldite LY560 pada dasarnya merupakan lem batu yang digunakan untuk merekatkan batu candi di Balai Konservasi Borobudur. Museum Manusia Purba Sangiran mendapatkan araldite tersebut dari Balai Pelestarian Peninggalan Purbakala Jawa Tengah. Campuran kimiawi araldite pada dasarnya terdiri dari resin epoxide yang dicampur dengan hardener. Penggunaan Araldite LY560 dilakukan sejak tahun 1990 hingga 2009 saat museum mulai menggunakan epoxy resin untuk menyambungkan potongan fosil (wawancara dengan Paiman). Epoxy resin secara umum memiliki campuran kimiawi yang sama dengan araldite. Perbedaan di antara keduanya hanya pada merek dagang serta takaran yang diperlukan antara campuran resin dan hardener dari Araldite LY560 dan epoxy resin. Pada Araldite LY560 diperlukan campuran resin dan hardener dengan takaran 4:1, sedangkan epoxy resin memerlukan campuran resin dan hardener dengan perbandingan 1:1 (wawancara dengan Widiyono, Utama, dan Yudha).

Alasan penggantian bahan perekat menjadi epoxy resin karena pada saat itu Araldite LY560 diperoleh dengan cara mengimpor dari Singapura dan harganya mahal apabila dibandingkan dengan epoxy resin (wawancara dengan Paiman). Araldite LY560 dan epoxy resin sama-sama memiliki proses pengeringan selama 24 jam. Sebelum mengaplikasikan bahan perekat, sisi potongan fosil yang akan direkatkan perlu dibersihkan terlebih dulu agar sambungannya dapat merekat dengan baik. Sejauh ini belum ada penelitian yang membandingkan antara daya rekat serta ketahanan dari Araldite LY560 dan epoxy resin. Keduanya sama-sama digunakan untuk merekatkan potongan fosil yang berukuran besar karena memiliki daya rekat yang kuat serta kemungkinan untuk menggeser sambungan apabila ada kesalahan dalam merekatkan potongan fosil karena dibutuhkan 24 jam untuk Araldite LY560 dan epoxy resin untuk mengering (wawancara dengan Widiyono dan Utama).

Epoxy resin merupakan salah satu bahan perekat yang termasuk ke dalam kelompok perekat termoset dan mengandung senyawa kimia epoxide. Bahan perekat epoxy resin biasanya terdiri atas dua komponen yang apabila dicampurkan akan membentuk polimer ikatan silang yang kuat (rigid cross-linked polymer). Epoxy resin tidak memerlukan pelarut sehingga tidak terjadi penyusutan saat mengeras. Kelebihan lainnya, yaitu reaksi kimianya tidak menghasilkan gas beracun, tahan air, serta memiliki daya rekat kuat yang awet. Meski begitu, epoxy resin memiliki kekurangan berupa perubahan warna yang menggelap seiring berjalannya waktu, meninggalkan endapan residu resin yang mengilap pada permukaan, serta sifatnya yang tidak berbalik (Elder dkk. 1997; Ginell dan Coffman 1998; Thornton 2005).

Selain menggunakan epoxy resin sebagai bahan perekat, Museum Manusia Purba Sangiran juga menggunakan lem super $\mathrm{G}$ Tong Shen untuk merekatkan temuan fosil yang berukuran kecil. Lem super $\mathrm{G}$ Tong Shen merupakan merek dagang dari bahan perekat cyanoacrylate yang secara generik mencakup lem cair yang memiliki daya kering dalam waktu singkat (Thornton 2005). 
Penggunaan Bahan Perekat Epoxy Resin dan Cyanoacrylate Konservasi Koleksi Fosil di Museum Manusia Purba Sangiran, Jawa Tengah - Pratamanita Rahayu dan Andi Putranto (43-58)

Doi: $10.24832 / n w . v 15 i 1.454$

Kelebihan dari lem super $G$ Tong Shen sebagai bahan perekat, antara lain tidak membutuhkan campuran yang berfungsi sebagai pengeras sehingga pengunaannya tidak sukar, warnanya bening, dapat diperoleh dengan mudah, harganya murah, serta waktu yang dibutuhkan untuk mengering sangat singkat. Kekurangan dari bahan perekat ini adalah stabilitas kimiawinya buruk dan ikatan perekatnya melemah dalam jangka panjang, kemungkinan munculnya retakan, serta degradasi parah dalam keadaan alkali (Elder dkk. 1997; Thornton 2005). Selain itu, sambungan fosil yang menggunakan bahan perekat ini dapat meleleh dan lepas apabila terkena larutan paraloid. Oleh karenanya, penggunaan bahan perekat ini ditambahkan campuran pasir dan bubuk fosil agar tidak meleleh saat terkena larutan paraloid. Campuran pasir dan bubuk fosil tersebut berfungsi pula untuk menyelaraskan warna sambungan dengan warna asli fosilnya (wawancara dengan Widiyono dan Utama).

\section{Dampak Penggunaan Bahan Perekat pada Koleksi Fosil Museum Manusia Purba Sangiran}

Pengamatan terhadap fosil yang diberi penangan konservasi dilakukan tanpa menggunakan peralatan laboratorium. Koleksi yang diberi bahan perekat diamati secara visual dengan mata telanjang. Dampak penggunaan bahan perekat pada koleksi dinilai berdasarkan pada penampakan spesimen fosil setelah diberi penanganan konservasi dengan menggunakan bahan perekat. Sampel koleksi fosil diletakkan di atas kain berwarna hitam sebagai latar belakang agar warna asli krem kecokelatan dari fosil dapat terlihat jelas. Koleksi fosil yang akan didokumentasikan disertai pula dengan skala berukuran $15 \mathrm{~cm}$ sebagai perbandingan, kecuali untuk satu koleksi fosil Stegodon sp, yang menggunakan skala berukuran $25 \mathrm{~cm}$. Foto-foto diambil dengan menggunakan kamera saku digital Sony HX9V dengan tingkat ISO 800 dan tanpa mengunakan lampu kilat. Berikut hasil pengamatan langsung terhadap kesembilan sampel koleksi fosil,

\section{Famili Trionychidae (NIV Tri/0166/BPSMPS/09)}

Trionychidae merupakan famili dari genera kura-kura bercangkang lunak (softshell turtles) yang dikenal sebagai bulus atau labi-labi. Bagian fosil yang dijadikan sampel penelitian ini merupakan fragmen dari plastron, yaitu cangkang yang melindungi bagian dada kura-kura. Fragmen fosil tersebut memiliki berat 50 gram dan diperoleh dari kegiatan ekskavasi pada lapisan Pucangan di situs Sangiran. Fragmen plastron tersebut diberi penanganan konservasi dengan menggunakan bahan perekat berupa lem super $G$ Tong Shen yang diberi campuran pasir dan bubuk fosil sebagai kamuflase serta direkatkan dengan kapas sebagai media perantaranya (Tabel 3).

Pada fosil fragmen plastron tersebut tampak celah sambungan yang mengindikasikan bahwa potongan-potongan tersebut tidak menyambung sejajar dengan baik (Gambar 1). Hal ini seringkali disebabkan oleh munculnya retakan pada spesimen fosil saat diangkat dari situs serta material komponen fosil yang menjadi rapuh karena fluktuasi kelembapan relatif $(\mathrm{RH})$ saat pengeringan.

Sambungan pada fosil fragmen plastron tersebut tampak kasar dan berpasir yang apabila diraba terasa berbutir. Hal ini merupakan salah satu efek penggunaan lem cyanoacrylate yang menjadi rapuh seiring berjalannya waktu (Tabel 3). Oleh karena tidak tersedianya foto fosil sebelum dan sesudah diberi penanganan konservasi dari tahun 2009, tidak dapat dilakukan perbandingan untuk melihat ada tidaknya perbedaan penampakan fosil untuk melihat efek jangka panjang penggunaan lem super sebagai bahan perekat.

\section{Stegodon sp. (NIV Elp/1228/BPSMPS/10)}

Stegodon sp. merupakan salah satu genus dari famili Stegodontidae yang telah punah dari ordo Proboscidea. Beberapa peneliti (Kalb dan Frohelich 1995) berpendapat bahwa genus Stegodon sp. termasuk ke dalam famili Elephantidae. Stegodon hidup di sebagian besar wilayah Asia pada kala Pliosen dan Pleistosen sekitar 11,6 juta hingga 11.000 tahun yang lalu. Fosil Stegodon di Museum Manusia Purba Sangiran sebagian besar diperoleh dari situs Ngandong, Patiayam, Trinil, dan Sangiran.

Sampel koleksi fosil Stegodon untuk penelitian ini adalah tulang atlas. Fosil tersebut didapatkan dari lokasi situs Sangiran dan memiliki berat 1.375 gram. Pada label koleksi tidak dituliskan siapa penemunya 
ataupun lapisan ditemukannya fosil tersebut. Koleksi fosil diberi penanganan konservasi dengan menggunakan bahan perekat berupa campuran epoxy resin dan hardener dengan takaran 1:1. Fosil tersebut juga diberi campuran pasir dan bubuk fosil untuk menyamarkan sambungan (Tabel 2).

Pada fosil tulang atlas (Gambar 2) terlihat adanya sambungan berbentuk garis vertikal pada sisi atas (B) dan sisi bawah (A). Penggunaan campuran pasir beserta bubuk fosil nyaris menyamarkan hasil konservasi dengan menggunakan perekat. Hal tersebut dapat dilihat pada sambungan fosil. Tidak terlihat adanya endapan residu epoxy resin pada permukaan fosil. Penggunaan epoxy resin dan hardener biasanya dapat terlihat dari kelebihan perekat yang mengeras dan meninggalkan wujud padat mengilap berwarna gelap pada permukaan fosil. Meskipun begitu, pada sambungan fosil tampak garis gelap kehitaman yang merupakan dampak dari penggunaan epoxy resin (Gambar 3). Epoxy resin menjadi agak kehitaman seiring berjalannya waktu.

\section{Stegodon sp. (NIV Elp/0965/BPSMPS/10)}

Sampel koleksi fosil costae sinistra dari Stegodon sp. berikut ditemukan di Grogolan dan Manyarejo, serta memiliki berat 3.000 gram. Meskipun berdasarkan nomor inventarisnya di database, koleksi ini masuk ke dalam kelompok tahun 2010, pada kolom tanggal di label koleksi tertulis tahun 2007. Perbedaan tahun ini berkaitan dengan pembaruan database yang dilakukan Museum Manusia Purba Sangiran pada tahun 2009.

Costae merupakan nama Latin dari tulang panjang melengkung yang membentuk rongga dada. Costae sinistra berarti tulang rusuk pada sisi kiri. Pada fosil tulang rusuk ini terdapat enam bagian yang disambungkan dengan bahan perekat (garis sambungan vertikal pada fosil) dan suatu sambungan horizontal antara sambungan ketiga dan sambungan keempat (Gambar 4).

Fosil direkatkan dengan menggunakan campuran epoxy resin dan hardener dengan takaran 1:1. Selain itu, sambungan pada fosil juga diberi campuran pasir dan bubuk fosil untuk menyamarkan penggunaan bahan perekat agar bagian yang disambung terlihat alami seperti warna aslinya. Apabila diraba, bagian sambungan tersebut terasa berbutir meski tidak terasa berpasir (Tabel 2).

Meskipun secara umum penggunaan bahan perekat disamarkan dengan menggunakan campuran pasir dan bubuk fosil, pada beberapa bagian fosil dapat terlihat jelas garis sambungan tersebut. Penampakan garis sambungan yang terlihat jelas tersebut dapat disebabkan oleh pecahan fosil yang tidak dapat menyambung dengan baik yang diakibatkan oleh pembengkokan saat pengangkutan atau pengeringan.

Dampak yang paling menonjol dari penggunaan epoxy resin sebagai bahan perekat pada spesimen fosil adalah perubahan warna bahan perekat menjadi kehitaman seiring waktu. Garis sambungan potongan-potongan fosil costae sinistra dari Stegodon sp. tersebut terlihat gelap agak kehitaman dibandingkan dengan warna asli fosilnya.

Pada beberapa bagian sambungan juga dapat terlihat endapan residu dari bahan perekat. Residu tersebut mengindikasikan penggunaan bahan perekat pada konservasi fosil. Sebagai contoh, terlihat bagian yang sedikit berkilap di permukaan fosil pada daerah sekitar sambungan (lingkaran merah (a) pada Gambar 5). Pada penggunaan bahan perekat epoxy resin dan hardener, rembesan yang mengeras tersebut menyebabkan munculnya endapan berkilap (glossy film) berwarna gelap agak kehitam-hitaman pada permukaan fosil. Akan tetapi, kilapan pada permukaan fosil Stegodon sp. pada (Gambar 6) terlihat bening.

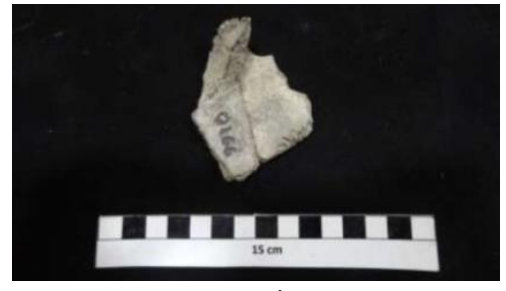

Sumber: Dok. Peneliti

Gambar 1 Tampak Bawah Fragmen

Plastron dari Famili Trionychidae

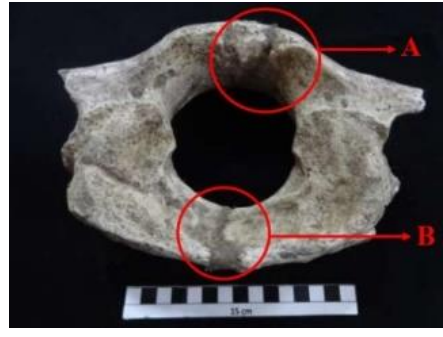

Sumber: Dok. Peneliti

Gambar 2 Tampak Bawah Fosil Tulang Atlas Stegodon sp.

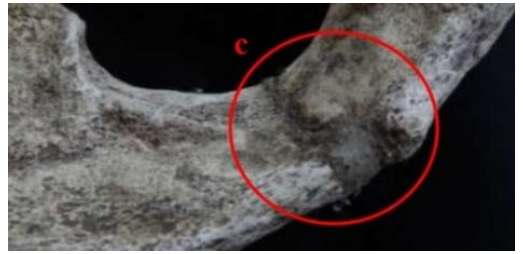

Sumber: Dok. Peneliti

Gambar 3 Tampak Bawah Sambungan B Fosil Tulang Atlas Stegodon sp. 


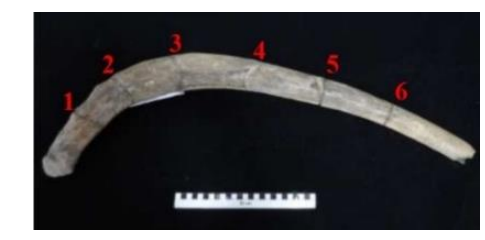

Sumber: Dok. Peneliti

Gambar 4 Tampak Sambungan pada Fosil Tulang Rusuk Stegodon sp.

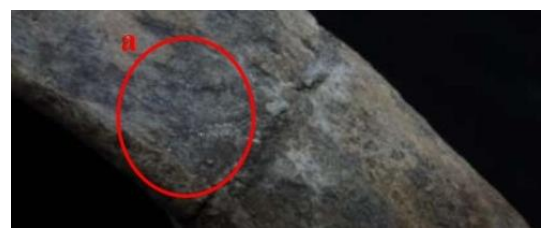

Sumber: Dok. Peneliti

Gambar 5 Endapan Berkilap sekitar Sambungan Kedua pada Fosil Tulang Rusuk Stegodon sp.

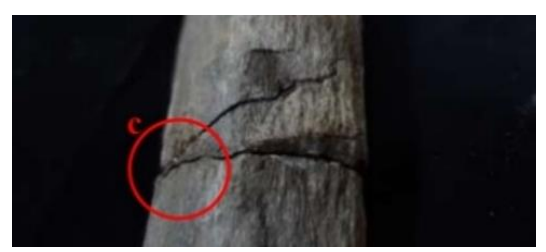

Sumber: Dok. Peneliti

Gambar 6 Sambungan Kelima pada

Fosil Tulang Rusuk Stegodon sp.

\section{Bubalus palaeokarabau (NIV Bov/0500/BPSMPS/2010)}

Bubalus palaeokarabau merupakan spesies kerbau bertanduk panjang yang termasuk ke dalam genus Bubalus (Popenoe 1983 dalam Croft, Heaney, dan Bautista 2006). Spesies yang telah punah ini tersebar di Indonesia pada periode Kuarter. Fragmen fosil cornu sinistra (tanduk kiri) dari Bubalus palaeokarabau yang diamati untuk penelitian ini memiliki berat 7.000 gram.

Fragmen cornu sinistra tersebut diberi penanganan konservasi dengan menggunakan bahan perekat. Hal itu dapat dilihat dari sambungan fosil yang dilingkari pada Gambar 7. Sambungan fosil tidak terlihat jelas pada tampak atas (Gambar 8), tetapi terlihat sangat jelas pada tampak bawah (Gambar 9). Sambungan fosil pada sisi atas terasa kasar dan berbutir saat diraba, sedangkan sambungan fosil yang tampak jelas pada sisi bawah terasa agak sedikit lengket-lengket kesat.

Potongan fosil direkatkan menggunakan epoxy resin dan hardener dengan perbandingan 1:1. Campuran pasir dan bubuk fosil juga diaplikasikan untuk menyamarkan sambungan pada fosil tersebut. Fosil yang direkatkan dengan epoxy resin dan hardener membutuhkan waktu selama kurang lebih 24 jam agar sambungannya mengeras. Ada kemungkinan saat koleksi fosil diletakkan, cairan bahan perekat merembes dan mengering meninggalkan bekas berkilap pada permukaan fosil (Tabel 2).

Kilap yang terlihat pada permukaan fosil merupakan tanda bahwa fosil diberi penanganan konservasi dengan menggunakan epoxy resin dan hardener sebagai bahan perekat. Penggunaan epoxy resin dan hardener biasanya meninggalkan wujud padat mengilap pada permukaan fosil apabila tidak diberi pasir dan bubuk fosil. Jika dilihat dari estetikanya, akan lebih baik apabila pada setiap sambungan diberi pasir dan bubuk fosil untuk menyamarkan bagian fosil yang disambung tersebut.

\section{Bos sp. (NIV Bov/1222/BPSMPS/2011)}

Bos sp. merupakan genus sapi, baik domestik maupun liar, yang termasuk dalam famili Bovidae. Spesimen koleksi yang dijadikan sampel penelitian ini adalah mandibula dextra yang merupakan tulang rahang bawah bagian kiri. Fosil mandibula dextra dari Bos sp. tersebut ditemukan di lapisan Kabuh di situs Sangiran.

Apabila dilihat sepintas, fosil mandibula dextra tersebut tampak telah diberi penanganan konservasi dengan bahan perekat pada seluruh bagiannya (Gambar 10). Akan tetapi, apabila diperhatikan dengan seksama, bagian yang berwarna cokelat muda agak krem merupakan warna asli dari fosil tersebut dan bagian yang berwarna gelap agak kehitaman adalah bagian yang diberi bahan perekat.

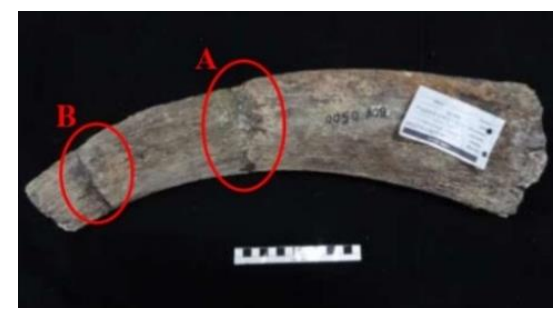

Sumber: Dok. Peneliti

Gambar 7 Fragmen Fosil cornu sinistra dari Bubalus Palaeokarabau

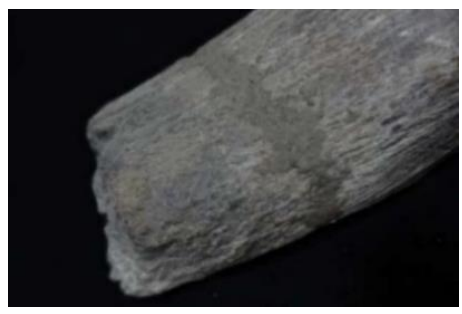

Sumber: Dok. Peneliti

Gambar 8 Tampak Atas Sambungan Fosil cornu sinistra dari Bubalus Palaeokarabau 


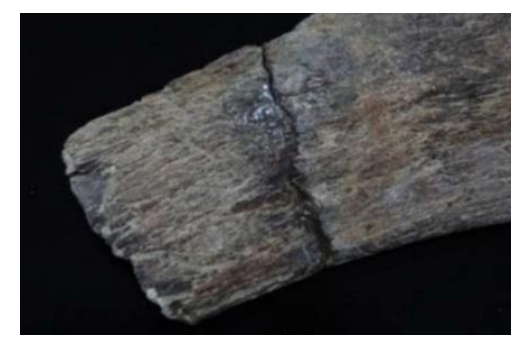

Sumber: Dok. Peneliti

Gambar 9 Tampak Bawah Sambungan Fosil cornu sinistra dari Bubalus Palaeokarabau

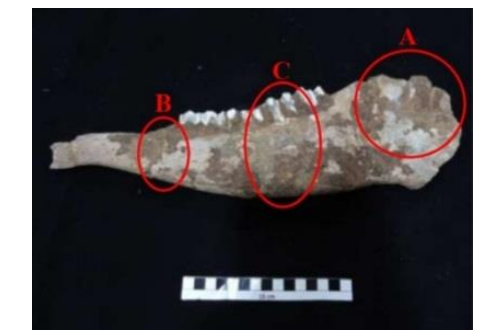

Sumber: Dok. Peneliti

Gambar 10 Tampak Bawah Fosil mandibula dextra dari Bos sp.

Pecahan-pecahan fosil mandibula dextra dari Bos sp. tersebut direkatkan dengan mengunakan epoxy resin yang dicampur dengan hardener dengan takaran 1:1. Warna gelap yang muncul pada permukaan fosil tersebut mengindikasikan penggunaan epoxy resin dan hardener. Meskipun biasanya warna gelap tersebut disertai dengan endapan mengilap, pada fosil mandibula dextra ini endapan tersebut tidak ada. Bagian sambungan pada fosil juga diberi campuran pasir dan bubuk fosil (Tabel 2).

Pada sambungan fosil Bos sp. tersebut ditemukan bagian yang menghitam. Apabila diraba, bagian tersebut terasa kasar dan berpasir serta terasa seperti karat besi (Gambar 11 dan 12). Hal tersebut menunjukkan bahwa fosil yang direkatkan dengan menggunakan epoxy resin memiliki kemungkinan deteriorasi dalam jangka panjang.

Penanganan konservasi fosil Bos sp. tersebut menyebabkan warna asli dari fosil nyaris tidak terlihat karena hampir seluruh permukaannya berwarna kehitaman yang disebabkan oleh penggunaan bahan perekat. Tidak hanya itu, fosil tersebut juga terlihat seperti diberi bahan perekat agar potongan-potongan serta pecahan-pecahan dari mandibula dextra tersebut dapat menyambung. Oleh karena itu, penampakan fosil mandibula dextra dari Bos sp. setelah diberi penanganan konservasi kuratif dapat dinilai kurang memuaskan secara estetika (aesthetically unpleasing). Padahal konservasi dilakukan tidak hanya untuk melestarikan kelangsungan dari koleksi museum, tetapi juga untuk menjaga keaslian dari koleksi tersebut. Di sisi lain, kegiatan konservasi tidak selalu dapat memenuhi seluruh prinsip-prinsip konservasi yang ada.

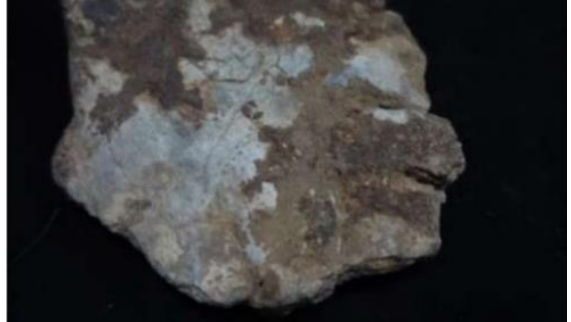

Sumber: Dok. Peneliti

Gambar 11 Bagian A Fosil mandibula dextra dari Bos sp.

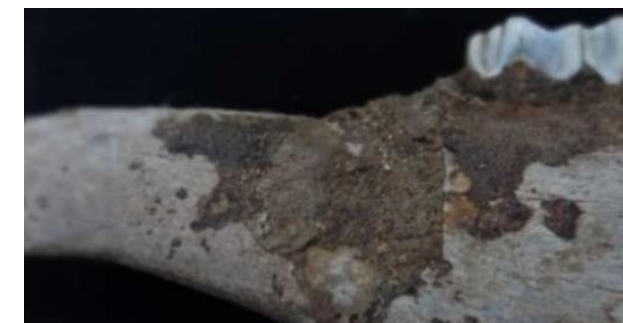

Sumber: Dok. Peneliti

Gambar 12 Bagian B Fosil mandibula dextra dari

Bos sp.

\section{Rhinoceros sp. (NIV 0086/Rhi/BPSMPS/12)}

Rhinoceros sp. merupakan genus binatang bercula satu bernama badak yang termasuk dalam famili Rhinocerotidae. Dua spesies yang termasuk ke dalam genus Rhinoceros adalah Rhinoceros unicornis, serta Rhinoceros sondaicus yang lebih dikenal dengan nama badak Jawa. Fosil yang dijadikan sampel penelitian ini merupakan fragmen humerus dextra dari Rhinoceros sp.. Dalam bahasa Indonesia, humerus dextra berarti tulang panjang pada tungkai depan hewan di sisi kiri. Meskipun dalam database Museum Manusia Purba Sangiran tidak tertulis secara jelas spesies dari fosil tersebut, besar kemungkinan bahwa fragmen humerus dextra tersebut merupakan tinggalan fosil Rhinoceros sondaicus.

Fosil fragmen humerus dextra dari Rhinoceros sp. tersebut diberi penanganan konservasi dengan menggunakan bahan perekat epoxy resin yang dicampur dengan hardener dengan perbandingan 1:1. Bagian sambungan fosil tidak diberi campuran pasir dan bubuk fosil sebagai kamuflase sehingga dapat terlihat jelas 
garis sambungan antara kedua potongan fosil yang telah direkatkan. Garis sambungan yang terlihat jelas pada fosil tersebut mengindikasikan bahwa fosil fragmen humerus dextra ini diberi bahan perekat (Gambar 13).

Penampakan garis sambungan yang terlihat jelas tersebut dapat disebabkan potongan fosil yang tidak dapat menyambung dengan baik karena potongannya tidak sesuai antara sisi satu dan lainnya, ataupun karena adanya celah dan retakan pada fosil yang diakibatkan oleh pengangkutan ke ruang penyimpanan.

Pada sambungan fosil tersebut pula terlihat adanya indikasi penggunaan epoxy resin yang dicampur dengan hardener sebagai bahan perekat untuk menyambungkan potongan fosil. Hal tersebut dapat dilihat pada endapan berwarna hitam mengilap di bagian yang dilingkari pada Gambar 14. Ciri-ciri penggunaan epoxy resin dan hardener adalah munculnya endapan hitam mengilap pada permukaan sambungan fosil (Tabel 2). Meski pada sambungan fosil Rhinoceros sp. tersebut terdapat endapan bahan perekat, hal itu tidak merusak penampakan fosil dilihat dari estetikanya.

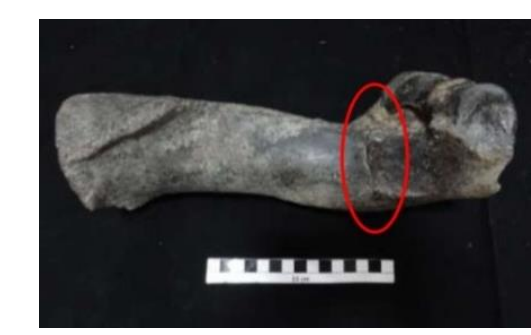

Sumber: Dok. Peneliti

Gambar 13 Tampak Sambungan pada Fosil humerus dextra dari Rhinoceros sp.

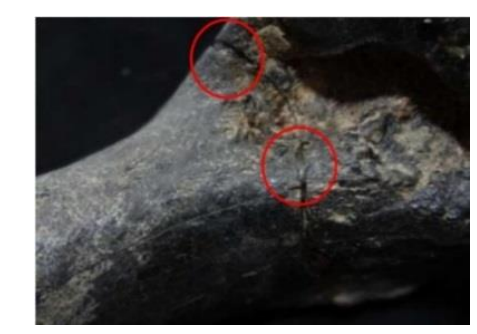

Sumber: Dok. Peneliti

Gambar 14 Endapan pada Sambungan Fosil humerus dextra dari Rhinoceros sp.

\section{Famili Elephantidae (NIV 1627/EIp/BPSMPS/2013)}

Elephantidae merupakan famili dari genera mamalia berukuran besar pemakan tumbuh-tumbuhan yang memiliki belalai dan termasuk ke dalam ordo Proboscidea. Sampel penelitian berikut merupakan fragmen pelvis dari famili Elephantidae. Pelvis adalah tulang panggul yang terhubung dengan tulang belakang dan tungkai pada hewan. Tidak seperti koleksi fosil lainnya yang dijadikan sampel penelitian, fosil fragmen pelvis Elephantidae ini merupakan satu dari dua koleksi yang dijadikan sampel yang memiliki foto awal pada saat fosil ditemukan dan belum diberi penanganan konservasi (Gambar 15).

Fosil fragmen pelvis Elephantidae tersebut diperoleh dari lapisan Pucangan di Ngampon dan telah diberi penanganan konservasi dengan menggunakan epoxy resin dan hardener sebagai bahan perekat dengan takaran 1:1. Fosil tersebut tidak diberi campuran pasir dan bubuk fosil yang biasanya digunakan sebagai kamuflase untuk bagian yang disambung (Gambar 16).

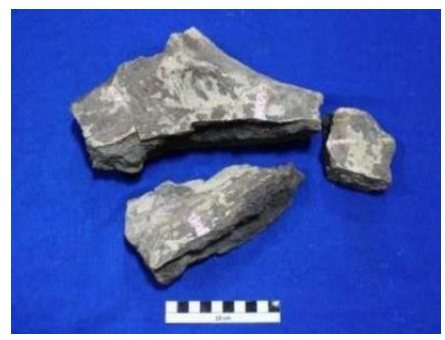

Sumber: database BPSMPS

Gambar 15 Fosil Sebelum Diberi Penanganan Konservasi

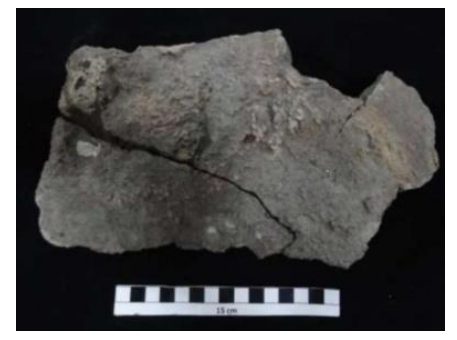

Sumber: Dok. Peneliti

Gambar 16 Tampak Atas Fragmen Fosil Pelvis dari

Elephantidae

Terdapat retakan-retakan yang terlihat jelas pada permukaan fosil fragmen pelvis tampak bawah. Munculnya retakan-retakan tersebut pada permukaan fosil tersebut dapat disebabkan oleh pengangkutan fosil dari situs ke museum, proses pengeringan fosil sebelum diberi penanganan konservasi dengan menggunakan bahan perekat, serta penyusutan karena perbedaan kelembapan relatif $(\mathrm{RH})$ di dalam tanah dan ruang 
penyimpanan (McCarty 2002 dalam Daniel 2007). Permukaan fosil terasa kasar dan berbutir serta agak berpasir saat diraba, sedangkan bagian sambungan yang direkatkan dengan menggunakan epoxy resin dan hardener terasa agak lengket dan kesat (Tabel 2).

Penggunaan epoxy resin dan hardener tampak sangat jelas pada fosil fragmen pelvis Elephantidae ini. Pada permukaan sambungan fosil sisi atas terlihat pada Gambar 17: (a) bagian yang menghitam pekat; dan (b) terlihat pula endapan bahan perekat yang mengilap. Pada sambungan fosil sisi bawah terlihat jelas endapan kehitaman berkilap (glossy film) (Gambar 18).

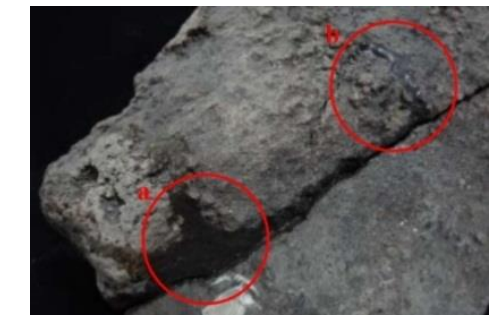

Sumber: Dok. Peneliti

Gambar 17 Tampak Atas Sambungan Fragmen Fosil Pelvis dari Elephantidae

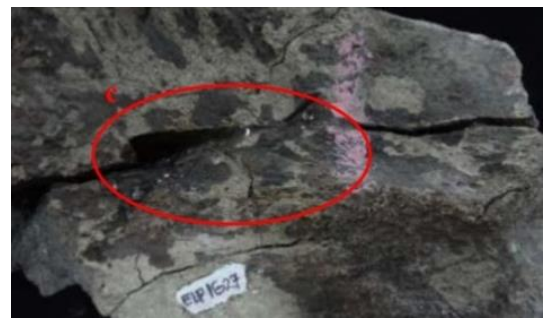

Sumber: Dok. Peneliti

Gambar 18 Tampak Bawah Sambungan Fragmen Fosil Pelvis dari Elephantidae

\section{Kelas Mamalia (NIV 0022/Mam/BPSMPS/2014)}

Mamalia merupakan kelas hewan vertebrata dengan karakteristik utama memiliki kelenjar susu. Terdapat 26 ordo yang termasuk ke dalam kelas Mamalia (Wilson dan Reeder 2005) serta lebih dari 5.400 spesies yang hidup pada masa kini. Karakteristik utama lain dari kelas Mamalia adalah endoterm, memiliki rambut, jantungnya terdiri atas empat ruang, sistem peredaran darah diatur oleh otak, serta tiga tulang pendengaran pada tiap-tiap telinga.

Koleksi fosil berikut merupakan fragmen tulang kaki dari kelas Mamalia yang diperoleh dari lapisan Kabuh di Tanjung. Fragmen tulang kaki tersebut termasuk fosil dengan ukuran kecil berukuran panjang 11,1 $\mathrm{cm}$ dan lebar $4,3 \mathrm{~cm}$. Pada permukaan fosil tampak atas terlihat perbedaan warna yang lumayan mencolok pada sebagian sisi A permukaan fosil fragmen tulang kaki tersebut yang memiliki warna putih pucat agak krem, sedangkan sebagian besar sisi B berwarna cokelat gelap agak kekuningan. Perbedaan warna tersebut kemungkinan besar disebabkan oleh proses oksidasi dan reaksi kimia kalsium fosfat yang mengakibatkan perubahan warna (discoloration) menjadi kehitaman pada saat pengangkatan fosil dari situs dan juga selama proses pengeringan (air drying).

Fosil fragmen tulang kaki tersebut diberi penanganan konservasi dengan menggunakan lem super $G$ Tong Shen sebagai bahan perekat karena ukurannya yang kecil. Lem tersebut kemudian dicampur dengan campuran pasir dan bubuk fosil untuk menyamarkan sambungan pada fosil. Saat diambil dari ruang penyimpanan, kondisi spesimen fosil fragmen tulang kaki tersebut pecah terbagi dua. Potongannnya tepat berada di tengah-tengah bagian fosil (bagian yang ditunjuk panah pada Gambar 19). Berikut langkah-langkah penyambungan potongan fosil menggunakan lem super G Tong Shen:

- kedua sisi potongan fosil dibersihkan dari butiran-butiran pasir;

- siapkan kapas tipis sebagai media perantara perekat antara kedua potongan fosil;

- aplikaskan lem super G Tong Shen pada satu sisi potongan fosil dan beri lapisan kapas tipis. Tambahkan sedikit lem di sepanjang sisi potongan fosil. Pastikan kapas tipis tersebut basah oleh lem;

- sejajarkan kedua potongan fosil dan rekatkan dengan perlahan agar kedua potongan dapat menyambung secara paralel dengan baik. Kedua potongan fosil perlu disejajarkan sebelum direkatkan menjadi satu karena lem super $\mathrm{G}$ Tong Shen mengering dengan cepat sehingga diperlukan ketelitian dan kecepatan saat menyambungkan potongan fosil.

Peneliti tidak menggunakan campuran pasir dan bubuk fosil untuk menyamarkan sambungan fosil. Saat sambungan fosil sudah mengering, dilakukan pengamatan terhadap fosil fragmen tulang kaki Mamalia tersebut. Penggunaan kapas sebagai media penyambung dalam kegiatan konservasi fosil dengan menggunakan bahan perekat lem G Tong Shen seperti pada Gambar 20, yaitu (a) fosil fragmen tulang kaki 
Mamalia terlihat pada celah sambungan; dan (b) penggunaan lem super G Tong Shen dapat dilihat dari bagian yang agak mengilap di sekitar sambungan pada permukaan fosil (Tabel 3 ).

Pada sambungan fosil tampak atas tidak terlihat tanda-tanda penggunaan campuran pasir dan bubuk fosil sebagai kamuflase, tetapi pada tampak bawah fosil fragmen tulang kaki tersebut dapat terlihat penggunaan campuran pasir dan bubuk fosil. Campuran pasir dan bubuk fosil tersebut berasal dari kegiatan konservasi untuk merekatkan sambungan fosil sebelumnya, bukan yang dilakukan oleh peneliti. Saat diraba, sambungan tampak bawah fosil terasa kasar dan berpasir, sedangkan tampak atasnya terasa lebih mulus dan tidak terlalu berpasir.

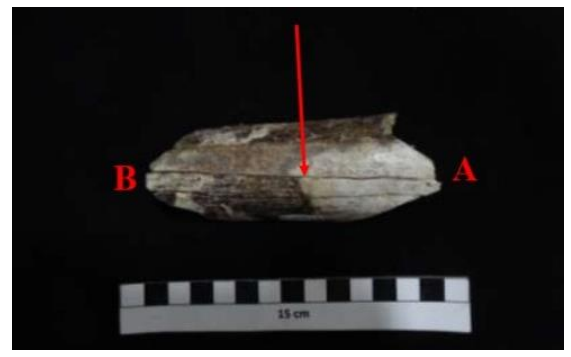

Sumber: Dok. Peneliti

Gambar 19 Tampak Atas Fragmen Fosil Tulang Kaki Mamalia

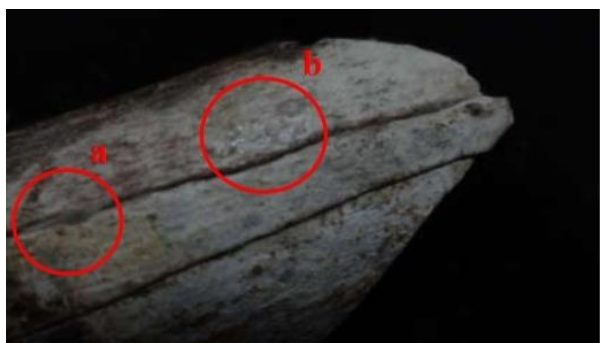

Sumber: Dok. Peneliti

Gambar 20 Tampak Atas Sisi A Fragmen Fosil Tulang Kaki Mamalia

\section{Felis sp. (NIV 006/Fel/BPSMPS/15)}

Felis sp. merupakan genus dari kelompok spesies kucing berukuran kecil dan medium yang termasuk ke dalam famili Felidae dari ordo Carnivora. Spesimen koleksi yang dijadikan sampel penelitian ini adalah fosil ulna sinistra dari Felis sp. yang diperoleh dari lapisan Pucangan di lokasi sebelah barat Ngampon. Ulna sinistra dalam bahasa Indonesia berarti tulang panjang sebelah kiri pada tungkai depan atau lebih dikenal dengan sebutan tulang hasta. Pada hewan berkaki empat umumnya, radius merupakan tulang utama penopang beban pada tungkai depan bawah, sedangkan ulna merupakan bagian tulang yang penting sebagai tempat melekatnya otot. Pada kebanyakan hewan kelas Mamalia, ulna menyatu sebagian ataupun seluruhnya dengan radius sehingga penyebutan antara keduanya sering kali tidak dibedakan (Romer dan Parsons 1977).

Koleksi fosil ulna sinistra dari Felis sp. berikut merupakan fosil kedua yang memiliki foto awal sebelum fosil diberi penanganan konservasi dengan menggunakan bahan perekat. Fosil tersebut terpotong-potong menjadi tujuh bagian (Gambar 21) yang kemudian disambungkan menjadi sebuah fosil ulna sinistra yang utuh.

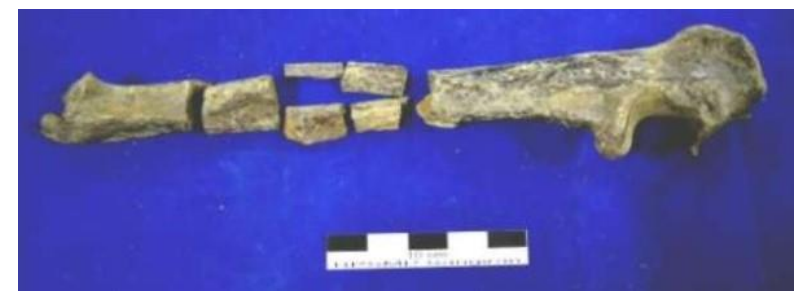

Sumber: database BPSMPS

Gambar 21 Temuan Fosil Ulna Sinistra dari Felis sp. sebelum diberi Penanganan Konservasi

Bahan perekat yang digunakan untuk menyambungkan potongan-potongan fosil ulna sinistra Felis sp. tersebut adalah epoxy resin dan hardener dengan perbandingan 1:1. Bagian sambungan fosil turut diberi campuran pasir dan bubuk fosil untuk menyamarkan sambungan serta menyelaraskan warna antara bagian yang diberi bahan perekat dan fosil itu sendiri. Apabila dilihat secara sekilas, sambungan pada fosil ulna sinistra tidak tampak jelas. Gambar 22 menampakkan hasil konservasi pada fosil setelah diberi penanganan dengan menggunakan bahan perekat. Bagian yang dilingkari pada Gambar 22 merupakan sambungan potongan fosil. 
Penggunaan bahan perekat berupa epoxy resin dan hardener dalam konservasi untuk menyambungkan potongan fosil dapat dilihat pada bagian sambungan yang menghitam (lingkaran b pada Gambar 23). Bagian sambungan yang menghitam tersebut terasa kasar dan berbutir saat diraba. Selain bagian sambungan yang menghitam tersebut, terdapat bagian sambungan yang mengilap menunjukan ciri lain dari panggunaan epoxy resin dan hardener (Tabel 2).

Meskipun sambungan pada fosil ulna sinistra dari Felis sp. telah diberi campuran pasir dan bubuk fosil sebagai kamuflase, pada beberapa bagian tetap terlihat garis sambungan potongan fosil tersebut. Potongan fragmen fosil yang tidak bisa menyambung secara sejajar dengan baik karena potongan fosil yang menyusut atau membengkok menyebabkan celah dan retakan sehingga sambungan pada fosil tetap terlihat (lingkaran $c$ dan d pada Gambar 23).

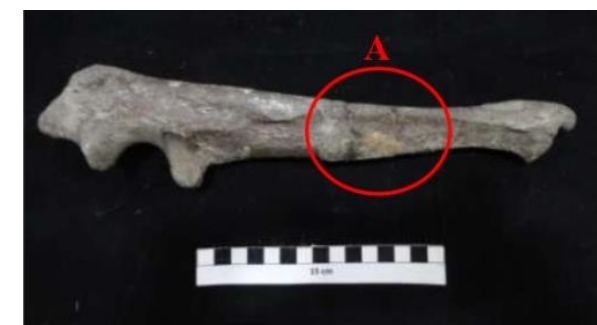

Sumber: Dok. Peneliti

Gambar 22 Tampak Atas Fosil ulna sinistra dari Felis sp.

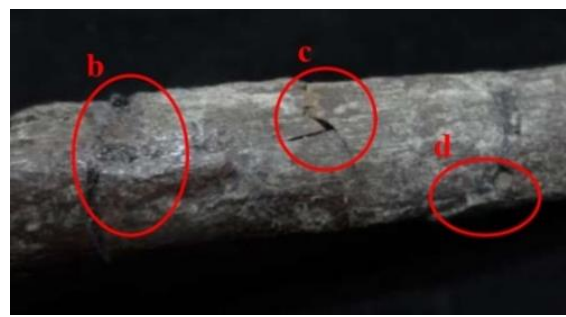

Sumber: Dok. Peneliti

Gambar 23 Perbesar Bagian B pada Fosil ulna sinistra dari Felis sp.

Tabel 2 Dampak Penggunaan Epoxy Resin pada Koleksi Fosil untuk Sampel Penelitian

\begin{tabular}{|c|c|c|c|c|c|}
\hline \multirow[b]{2}{*}{ No } & \multirow[b]{2}{*}{ Spesimen Fosil } & \multicolumn{4}{|c|}{ Dampak Penggunaan Epoxy Resin } \\
\hline & & $\begin{array}{l}\text { Warna sambungan } \\
\text { fosil gelap agak } \\
\text { kehitaman }\end{array}$ & $\begin{array}{l}\text { Endapan residu } \\
\text { resin mengilap } \\
\text { (glossy film) }\end{array}$ & $\begin{array}{l}\text { Endapan residu resin } \\
\text { terasa kesat dan agak } \\
\text { lengket saat diraba }\end{array}$ & $\begin{array}{c}\text { Sambungan fosil } \\
\text { terasa kasar dan } \\
\text { berbutir/berpasir } \\
\text { saat diraba } \\
\end{array}$ \\
\hline 1. & Stegodon sp. & $\sqrt{ }$ & --- & --- & --- \\
\hline 2. & Stegodon sp. & $\sqrt{ }$ & $\sqrt{ }$ & & $\sqrt{ }$ \\
\hline 3. & Bubalus palaeokarabau & $\sqrt{ }$ & $\sqrt{ }$ & $\sqrt{ }$ & $\sqrt{ }$ \\
\hline 4. & Bos sp. & $\sqrt{ }$ & -- & -- & $\sqrt{ }$ \\
\hline 5. & Rhinoceros sp. & $\sqrt{ }$ & $\sqrt{ }$ & $\sqrt{ }$ & --- \\
\hline 6. & Famili Elephantidae & $\sqrt{ }$ & $\sqrt{ }$ & $\sqrt{ }$ & --- \\
\hline 7. & Felis sp. & $\sqrt{ }$ & $\sqrt{ }$ & -- & $\sqrt{ }$ \\
\hline Jum & & 7 & 5 & 3 & 4 \\
\hline
\end{tabular}

Sumber: Hasil Penelitian penulis

Tabel 3 Dampak Penggunaan Lem Cyanoacrylate (G Tong Shen) pada Koleksi Fosil untuk Sampel Penelitian

\begin{tabular}{clcc} 
& \multirow{2}{*}{ No } & Spesimen Fosil & \multicolumn{3}{c}{ Dampak Penggunaan lem cyanoacrylate (G Tong Shen) } \\
\cline { 2 - 4 } & & $\begin{array}{c}\text { Terdapat bagian mengilap yang } \\
\text { transparan pada permukaan fosil }\end{array}$ & $\begin{array}{c}\text { Sambungan pada fosil terasa berbutir dan } \\
\text { berpasir (brittleness) saat diraba }\end{array}$ \\
\hline 1 & Famili Trionychida & -- & $\sqrt{ }$ \\
2 & Kelas Mamalia & $\sqrt{ }$ & $\sqrt{ }$ \\
\hline Jumlah & 1 & 2 \\
Sumber: Hasil Penelitian Penulis & &
\end{tabular}

\section{PENUTUP}

Berdasarkan analisis yang dilakukan terhadap koleksi fosil di Museum Manusia Purba Sangiran tersebut, dapat diketahui bahwa dampak dari penggunaan epoxy resin sebagai bahan perekat pada spesimen fosil adalah perubahan warna menjadi gelap kehitaman seiring waktu dan adanya endapan residu resin yang mengilap pada permukaan di sekitar sambungan fosil. Selain itu, endapan residu resin yang mengilap tersebut terasa kesat dan agak lengket saat diraba. Akan tetapi, pada beberapa kasus, sambungan fosil terasa kasar 
Penggunaan Bahan Perekat Epoxy Resin dan Cyanoacrylate Konservasi Koleksi Fosil di Museum Manusia Purba Sangiran, Jawa Tengah - Pratamanita Rahayu dan Andi Putranto (43-58)

Doi: $10.24832 / n w . v 15 i 1.454$

serta berbutir dan terkadang agak berpasir saat diraba. Sementara itu, dampak penggunaan lem cyanoacrylate $G$ Tong Shen dalam konservasi fosil adalah adanya residu transparan mengilap pada permukaan fosil serta sambungan yang terasa berpasir.

Pemilihan bahan perekat yang tepat untuk digunakan pada tindakan penyambungan dalam kegiatan konservasi kuratif fosil bukan merupakan perkara mudah. Hal tersebut sebagian bergantung pada kecakapan untuk menilai spesimen serta tugas yang harus ditangani dan sebagian lainnya tergantung pada pemahaman tentang bahan perekat yang tersedia untuk konservasi fosil. Selain itu pula, tidak ada bahan perekat paling baik secara definitif untuk digunakan dalam tindakan penyambungan fosil. Penggunaan bahan perekat yang berbeda pada setiap temuan spesimen fosil ataupun sub-fosil ditentukan berdasarkan tingkat kekerasan, material penyusun, serta kondisi situs ketika spesimen tersebut diperoleh. Oleh karena itu, berikut merupakan prospek penelitian lebih lanjut untuk meningkatkan kualitas penggunaan bahan perekat dalam kegiatan konservasi fosil, yaitu:

1. Penelitian penggunaan bahan perekat selain epoxy resin dan lem cyanoacrylate;

2. Apabila tidak dapat melakukan penelitian terhadap bahan perekat yang telah disebutkan dan akan tetap menggunakan epoxy resin sebagai bahan perekat, direkomendasikan untuk meminimalkan perubahan warna dari penggunaan epoxy resin dengan mengurangi kadar epoxy resin pada permukaan spesimen dan memilih resin yang lebih resistan terhadap perubahan warna.

\section{UCAPAN TERIMA KASIH}

Terima kasih atas kerja sama dan bantuan yang telah diberikan oleh Museum Manusia Purba Sangiran beserta segenap staf museum yang telah menjadi bagian dari penelitian ini.

\section{DAFTAR PUSTAKA}

Croft, D. A., L. R. Heaney, dan A. P. Bautista. 2006. "Fossil remains of a new, Diminutive Bubalus (Artiodactyla: Bovidae: Bovini) from Cebu Island, Philippines." Journal of Mammalogy (87):1037-51.

Daniel, Shanna L. 2007. A Mammoth of a Project: The Conservation of a Columbian Mammoth. Texas.

Elder, A., S. Madsen, G. Brown, C. Herbel, C. Collins, S. Whelan, C. Wenz, S. Alderson, dan L. Kronthal. 1997. "Adhesives and Consolidants in Geological and Paleontological Conservation: A Wall Chart." SPNHC Leaflets 1(2):1-4.

Ginell, William S. dan Richard Coffman. 1998. "Epoxy Resin-consolidated Stone: Appearance Change on Aging." Studies in Conservation 43:242-48.

Howie, Francis M. P. 1984. "Conservation and Storage: Geological Material." Hal. 308-17 in Manual of Curatorship: A Guide To Museum Practice, diedit oleh M. Thompson, John A., D. A. Basse, A. J. Dugga, G. D. Lew, dan A. Fenton. London: Butterworth Heinemann.

Iswidarti, Mega P. 2015. Perancangan Museum Anak-anak di Kota Malang. Malang.

Kalb, J. E. dan D. J. Frohelich. 1995. "Interrelationships of Late Neogene Elephantoids: New Evidence from the Middle Awash Valley, Afar, Ethiopia." Géobios 28:727-36.

Lewis, Geoffrey D. 1986. "Collections, Collectors and Museums: A Brief World Survey." Manual of Curatorship: A Guide To Museum Practice 7-22.

Romer, Alfred S. dan Thomas S. Parsons. 1977. The Vertebrate Body. 5th. Philadelphia, PA: Holt-Saunders International.

Sadirin, Hubertus. 2014. Dasar-dasar Konservasi Koleksi Museum. Jakarta: Pusat Pengembangan SDM Kebudayaan.

Sukronedi. 2012. "Konservasi Fosil." Jurnal Sangiran (1):57-68.

Thornton, Jonathan. 2005. Adhesives and Adhesion. New York: Buffalo State College.

Widianto, Harry dan Truman Simanjuntak. 2009. Sangiran Menjawab Dunia. Sragen: Balai Pelestarian Situs Manusia Purba Sangiran.

Wilson, D. E. dan D. M. Reeder. 2005. Mammal Species of the World: A Taxonomic and Geographic Reference (Vol. 1). Baltimore: The Johns Hopkins University Press. 